\section{First Record of Eotragus noyei from the Late Miocene Siwaliks of Pakistan}

\author{
Abdul Majid Khan',*, Muhammad Tahir Waseem', Rana Manzoor Ahmad², \\ Ayesha Iqbal ${ }^{1}$, Hafiza Imrana Naz ${ }^{1}$, Amtur Rafeh ${ }^{1}$ and Muhammad Ameen ${ }^{1}$ \\ ${ }^{1}$ Department of Zoology, University of the Punjab, Lahore 54590 \\ ${ }^{2}$ Department of Zoology, University of Okara, Okara, Punjab
}

\begin{abstract}
A B S T R A C T
The present paper reports the first record of Eotragus noyei from the late Miocene deposits of Dhok Pathan Formation, Chakwal, Pakistan. The sample comprises maxillary and mandibular fragments along with isolated upper and lower teeth. The morphometric analysis of the dental specimens led us to recognize the sample as belonging to Eotragus noyei, which has been considered as the smallest and the oldest bovid in the Siwaliks. Eotragus noyei is characterized by brachydont teeth, finely rugose enamel, more inclined buccal walls of the molars and small lingual cingula. The inclination of the metaconal area has caused rotation of the metastyle in relation to the antero-posterior tooth axis and thus situated more lingually. The protocone in second upper premolar is well developed and situated posteriorly and also has an anterior lingual constriction. The metaconule in the third upper molar is smaller than the protocone. The dentition in Eotragus noyei is smaller in size as compared to Eotragus sansaniensis and Eotragus lampangensis. In Eotragus noyei the buccal walls in molars are more inclined while in Eotragus sansaniensis, they are less inclined. The genus Eotragus has been reported previously in the Lower Siwaliks of Pakistan; however, the recognition of the present sample as Eotragus noyei has extended the range of this species from Lower to the Middle Siwaliks of Pakistan.
\end{abstract}

Article Information
Received 22 January 2020
Revised 24 February 2020
Accepted 04 March 2020
Available online 08 January 2021
Authors' Contribution
AMK, MTW and HIN designed
the study. AR, AI and RMA did the
taxonomic identification. MTW and
MA wrote the geological settings.
MTW, HIN and AMK wrote the
manuscript.
Key words
Boselaphini, Chakwal, Bovids, Dhok
Pathan, Middle Siwaliks.

\section{INTRODUCTION}

$\mathrm{S}$ waliks has been found to be having artiodactyls in its Miocene and Pliocene sediments and they are found to belong to the Middle Siwaliks, the exact location of which is in the Potwar Plateau of Northern Pakistan (Barry et al., 1982, 1985, 2002, 2013; Flynn et al., 2016; Waseem et al., 2016). These artiodactyls are found to have outstanding material which shows high diversity of boselaphine bovids in between late Miocene and early Pliocene. Bovids constitute $56 \%$ of the recovered artiodactyls out of which $29.7 \%$ are boselaphine. During the Eurasian, African and the Siwalik late Miocene, and still today, these boselaphine remains were abundant (Bibi, 2007, 2009). This indicates that the niche was fully occupied by boselaphines rather than tragilaphines. These tragilaphines were found to be more diverse during late Miocene in Africa and due to which boselaphines became extinct (Haile-Seliasse et al., 2004). This is evidence for abolition of habitat of late Miocene boselaphines (Khan et al., 2009; Badgley et al., 2008). Dental microwear and mesowear analysis of $E$. aff. clavatus reported from the Calatayud-Daroca Basin of Spain, Göriach (Australia) and Eotragus clavatus from Sansan (France) showed that

\footnotetext{
* Corresponding author: majid.zool@pu.edu.pk 0030-9923/2021/0002-0423 \$ 9.00/0

Copyright 2021 Zoological Society of Pakistan
}

both taxa were generalized browsers (Solounias and Moelleken, 1992). Extracted isotopes of oxygen and carbon from enamel of Mae Moh herbivores' tooth. indicate that they occupied various habitats ranging from grasslands to woodlands. The carbon isotope values for Mae Moh herbivore community ranges from $-12 \%$ to $-8.4 \%$ indicating the appearance of grasslands close to open forests and woodlands. Exclusively, carbon isotope that is found in E. lampangensis sp. nov. $\left(\delta^{13} \mathrm{C}=-8.4 \%\right.$ ) (Suraprasit et al., 2014) shows that it lived in between grassland and forest habitat which express more close relationship with moderate brachydonty. This paper reports the first occurrence of E. noyei from middle Dhok Pathan formation of the Siwaliks of Pakistan which extends the range of this species from late Middle Miocene to Late Miocene.

\section{MATERIALS AND METHODS}

The sample for the present study has been recovered from Dhok Pathan Rest House (33.12N, 72.34E), Dhok Pathan Formation, Chakwal, Pakistan. We assume that the sample belong to one individual. The complete magnetostratigraphic correlation with the section has been given in the Barry et al. (2002). The studied section comprised of multi storied sandstone more formally characterized as U-sandstone (Morgan et al., 2009). The sample can be placed between the magnetozone 4An and 
4Ar.1r on the basis of U-sandstone interval (Behrensmeyer and Tauxe, 1982). The total height of the section is $150 \mathrm{~m}$ at intervals it is $490 \mathrm{~m}$, while the samples for the current study has been recovered at the height of $90 \mathrm{~m}$. The correlation of section log and magnetic polarity given in Barry et al. (2002) allows us to place the sample between $8.5 \mathrm{Ma}$ to $9 \mathrm{Ma}$. Biostratigraphically the recoverd samples can be placed in Hipparion s.l. interval zone having an age of 9.5 Ma to 7.4 Ma (Barry et al., 1982).

Studied material was collected during the field trip of April, 2015. The main technique which was used is the partial excavation by using fine needles, hammers, chisels, hand knives and brushes of the samples and exposed slightly. The samples were further washed and treated with weak bleach so the sample may be cleaned. All the measurements were taken by vernier calipers and reported in millimeters while photography was done by Canon EOS-350D using the lens $18-55 \mathrm{~mm}$. The collected specimens were catalogued and preserved in palaeontology laboratory of Zoology department for dental taxonomic study. The tooth width and length were measured on the occlusal side. The catalogue numbers are abbreviated as PUPC (Punjab University Palaeontological Collection). The terminology and measurements of the teeth follows Gentry (1994).

\section{Systematic Palaeontology}

Family: Bovidae (Gray, 1821)

Subfamily: Bovinae (Gray, 1821)

Tribe: Boselaphini (Knottnerus-Meyer 1907)

Genus: Eotragus (Pilgrim, 1939)

Included species

E. haplodon Thenius, 1952; E. noyei Solounias et al., 1995; E. sansaniensis Lartet, 1851; E. cristatus Biedermann, 1873; E. halamagaiensis Ye, 1989 and $E$. artenensis Ginsburg and Heintz, 1968.

\section{Type species}

Eotragus noyei.

Type locality

Dhok Pathan village, Chakwal district (Middle Siwaliks), Potwar Plateau, Pakistan.

Geographic distribution

Central Europe, China, Israel, Kenya, Libya, Pakistan and Spain.

\section{Stratigraphic range}

Lower Siwaliks to Middle Siwaliks.

Table I.- Comparison of morphological characters among the studied specimen and the different species of Eotragus.

\begin{tabular}{|c|c|c|c|c|}
\hline Studied specimen & E. noyei & Eotragus sp. & E. sansaniensis & E. lampangensis \\
\hline Selenodont morphology & Selenodont morphology & Selenodont morphology & Selenodont morphology & Selenodont morphology \\
\hline Brachydont teeth & Brachydont teeth & Brachydont teeth & Brachydont teeth & Brachydont teeth \\
\hline Finely rugose enamel & Finely rugose enamel & Finely rugose enamel & Finely rugose enamel & Finely rugose enamel \\
\hline Narrow fossette & Narrow fossette & Narrow fossette & Narrow fossette & Narrow fossette \\
\hline Small in size & Small size & Small in size & Very large size & Very large size \\
\hline $\begin{array}{l}\text { Buccal walls of the upper } \\
\text { molar are more inclined }\end{array}$ & $\begin{array}{l}\text { Buccal walls of the upper } \\
\text { molar are more inclined }\end{array}$ & $\begin{array}{l}\text { Buccal walls of the upper } \\
\text { molar are more inclined }\end{array}$ & $\begin{array}{l}\text { Buccal walls of the upper } \\
\text { molar are less inclined }\end{array}$ & $\begin{array}{l}\text { Buccal walls of the upper } \\
\text { molar are less inclined }\end{array}$ \\
\hline $\begin{array}{l}\text { Parastyle is of medium } \\
\text { sized }\end{array}$ & $\begin{array}{c}\text { Parastyle is of medium } \\
\text { sized }\end{array}$ & $\begin{array}{c}\text { Parastyle is of medium } \\
\text { sized }\end{array}$ & & $\begin{array}{l}\text { Parastyle is well } \\
\text { developed }\end{array}$ \\
\hline $\begin{array}{l}\text { Mesostyle is of medium } \\
\text { sized }\end{array}$ & $\begin{array}{l}\text { Mesostyle is of medium } \\
\text { sized }\end{array}$ & $\begin{array}{c}\text { Mesostyle is of medium } \\
\text { sized }\end{array}$ & & $\begin{array}{l}\text { Mesostyle is well } \\
\text { developed }\end{array}$ \\
\hline $\begin{array}{l}\text { Paracone ribs are stronger } \\
\text { than the metacone ribs }\end{array}$ & $\begin{array}{l}\text { paracone ribs are stronger } \\
\text { than the metacone ribs }\end{array}$ & $\begin{array}{l}\text { paracone ribs are stronger } \\
\text { than the metacone ribs }\end{array}$ & & \\
\hline $\begin{array}{l}\text { A trace of cingulum } \\
\text { present }\end{array}$ & $\begin{array}{l}\text { A trace of cingulum } \\
\text { present }\end{array}$ & Cingulum absent & Large cingulum & Cingulum absent \\
\hline $\begin{array}{l}\mathrm{M}^{3} \text { metaconule is smaller } \\
\text { than the protocone }\end{array}$ & $\begin{array}{l}\mathrm{M}^{3} \text { metaconule is smaller } \\
\text { than the protocone }\end{array}$ & & $\begin{array}{l}\mathrm{M}^{3} \text { metaconule is larger } \\
\text { than the protocone }\end{array}$ & $\begin{array}{l}\mathrm{M}^{3} \text { metaconule is larger } \\
\text { than the protocone }\end{array}$ \\
\hline $\begin{array}{l}\mathrm{P}^{2} \text { protocone is well } \\
\text { developed in the studied } \\
\text { specimen and situated } \\
\text { posteriorly }\end{array}$ & $\begin{array}{c}\mathrm{P}^{2} \text { protocone is well } \\
\text { developed in the studied } \\
\text { specimen and situated } \\
\text { posteriorly }\end{array}$ & & & \\
\hline
\end{tabular}

Source: Gentry (1999), Solounias et al. (1995), Khan et al. (2009) and ven der Made (2012). 


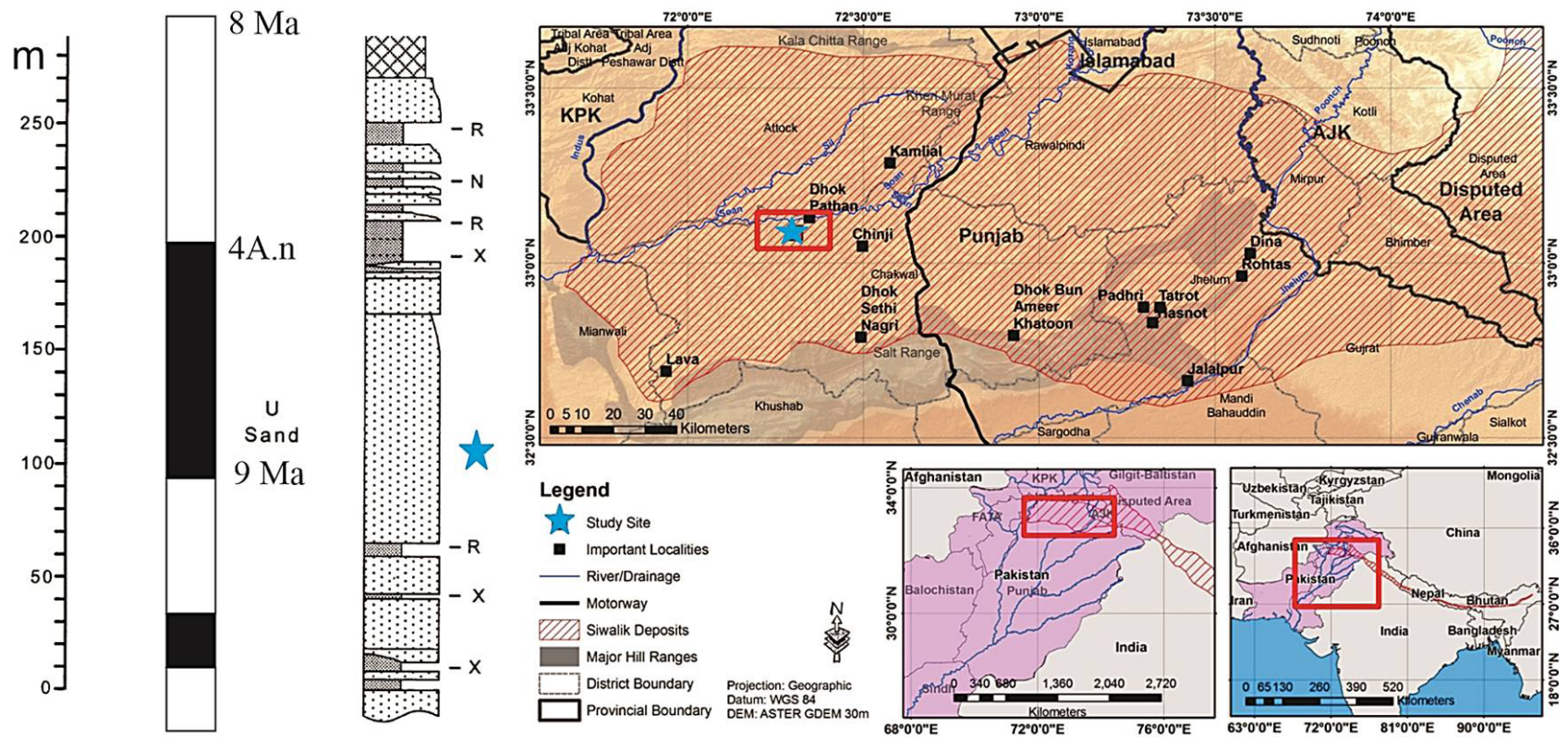

Fig. 1. Map of the Siwaliks of Pakistan with the studied locality and magnetostratigraphic chart (modified from Barry et al., 2002;

Morgan et al., 2009).

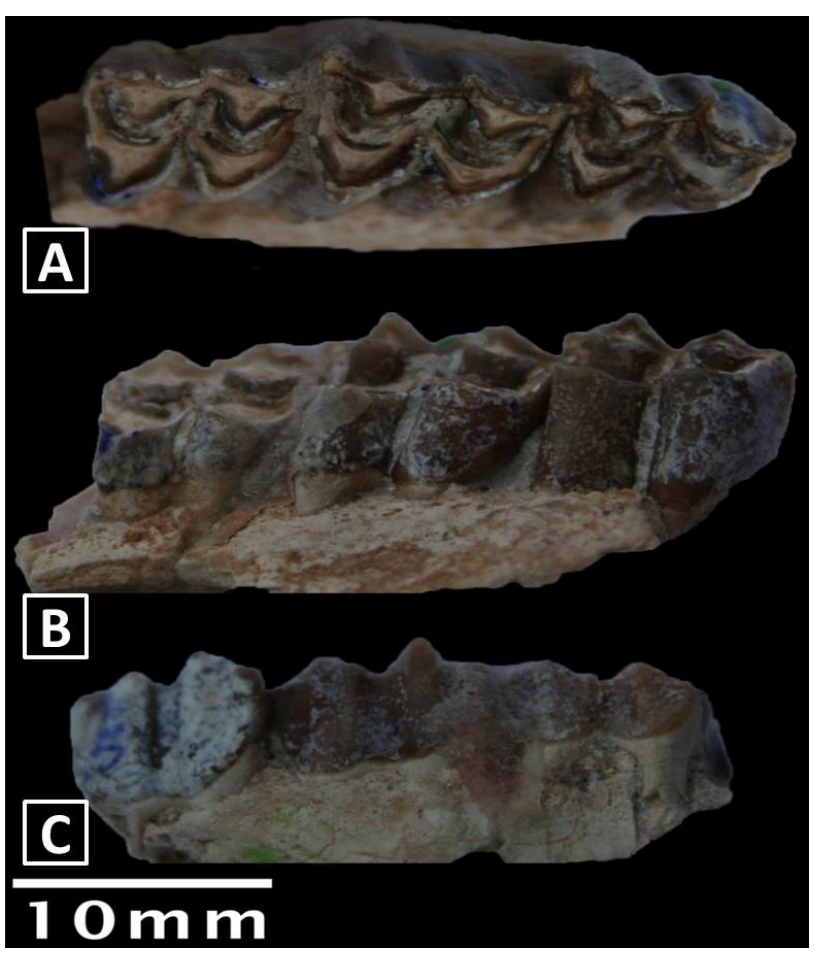

Fig. 2. Eotragus noyei. PUPC 16/353, left maxillary fragment having $\mathrm{M}^{1-3}$. A, occlusal view; $\mathrm{B}$, lingual view; $\mathrm{C}$, buccal view.

\section{Studied material}

Upper dentition: PUPC 16/353, left maxillary fragment having $\mathrm{M}^{1-3}$; PUPC 16/354, right maxillary fragment having $\mathrm{P}^{2}-\mathrm{M}^{3}$; PUPC 16/355, an isolated upper left second premolar $\left(\mathrm{P}^{2}\right)$. Lower dentition: PUPC 16/356, an isolated lower left third molar $\left(\mathrm{m}^{3}\right)$; PUPC 16/357, right mandibular fragment having $\mathrm{p}^{4} \mathrm{~m}^{3}$.

\section{Upper dentition}

PUPC 16/353 (Fig. 2) is a left maxillary fragment having $\mathrm{M}^{1-3}$. Its state of preservation is good. The molars are brachydont and quadrate in general appearance. A layer of cement is observed on the fragment. They have selenodont morphology and have finely rugose enamel. A piece of the palate is attached with the maxillary fragment. The buccal walls of the teeth do not align as the teeth are arranged obliquely. The anterior and posterior fossettes are rather narrow. The first molar is in the middle stage of wear. All the cusps are clearly visible and well developed while the styles are poorly developed. The protocone is more projected towards the lingual side. The teeth show the confluence of the premetacrista, postmetacrista and the postparacrista. Cingulum is absent on the fragment. The second molar is half worn causing the exposure of dentine of all the cusps. The protocone is isolated and slightly rounded. The posterior rib is weaker than the anterior rib. The size of parastyle, mesostyle and metastyle is medium. The lingual groove is not clearly visible due to middle stage of wear. The third molar has a comparable morphology to $\mathrm{M}^{2}$ and almost equal in size to $\mathrm{M}^{3}$. In the third molar, the metaconule is smaller than the protocone. PUPC 16/354 (Fig. 3) have similar dental morphology to PUPC 16/353. 


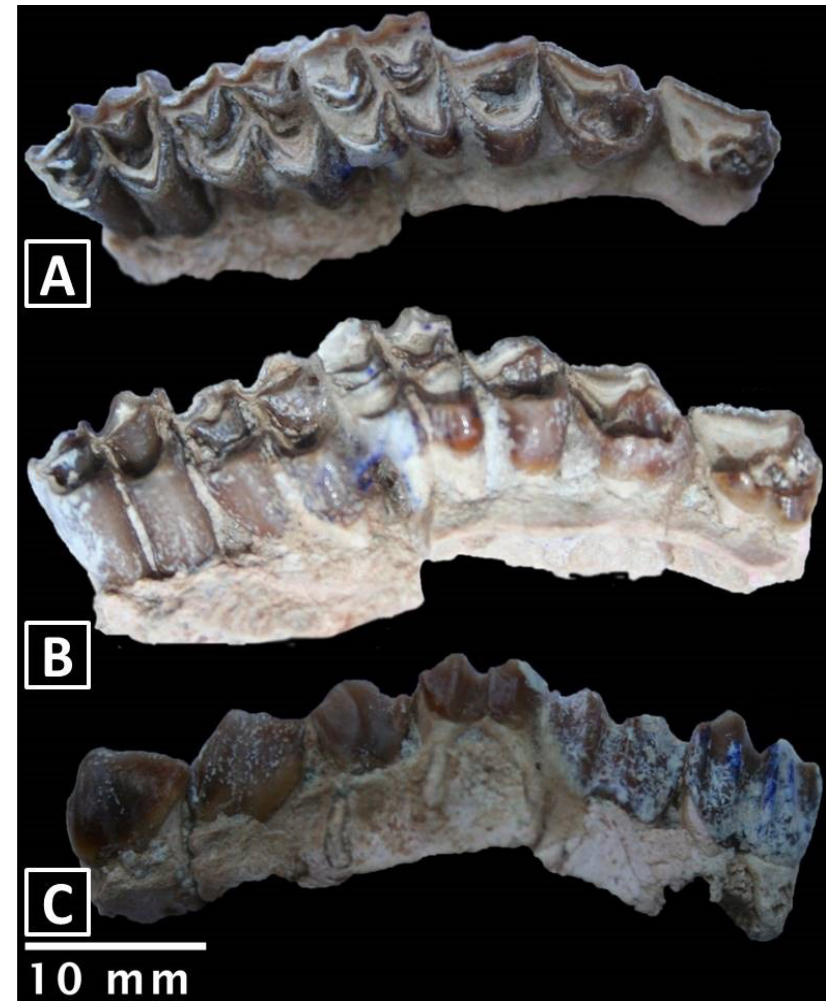

Fig. 3. Eotragus noyei. PUPC 16/354, right maxillary fragment having $\mathrm{P}^{2}-\mathrm{M}^{3}$. A, occlusal view; $\mathrm{B}$, lingual view; $\mathrm{C}$, buccal view.

PUPC 16/355 (Fig. 4A) is an isolated upper left second premolar. Its length is $8 \mathrm{~mm}$. It is well preserved. It is triangular in shape. It has well developed and clearly visible cusps. The protocone is well developed and located posteriorly and it has an anterior lingual constriction.

\section{Lower dentition}

PUPC 16/356 (Fig. 4B) is an isolated lower left third molar. It is moderately worn and has selenodont morphology. The enamel is finely rugose. The length of third molar is $12.5 \mathrm{~mm}$. It is rectangular by its appearance. A layer of cement is present on it. The protoconid is rounded and isolated. The mesostylid is less developed. The lower third molar has an additional cusp, known as talonid. The Central fossettes are isolated from the exterior. It has a weak metastylid. The posterior rib is weaker than the anterior one. All tooth features are well preserved and exhibit the confluence of protocristid, metacristid and the post metacristid.

PUPC 16/357 (Fig. 5) is a right mandibular fragment having $\mathrm{P}_{4} \mathrm{M}_{3}$ with a length of $39 \mathrm{~mm}$. The state of preservation of the mandible fragment is average. It is rectangular in general appearance. Its buccal side is more rugose than lingual side. The molar is brachydont and narrow crowned. A thick layer of cement is present on the whole fragment. Cracks are present on the molars. On the buccal sides of molars, median basal pillars or entostyles are present in the transverse valley. The $\mathrm{P}_{4}$ is elongated in shape and cones and styles are not visible. $M_{1}$ is not clearly visible. In $M_{2}$ stylids are less developed. The enamel is rugose especially on the buccal side of the mandible fragment. The lower right third molar, is moderately worn, dainty, with selenodont morphology and has a weak metastylid and anterior rib on its lingual wall. In the third a well-developed talonid is present. The cusp tips are rounded and sharp.

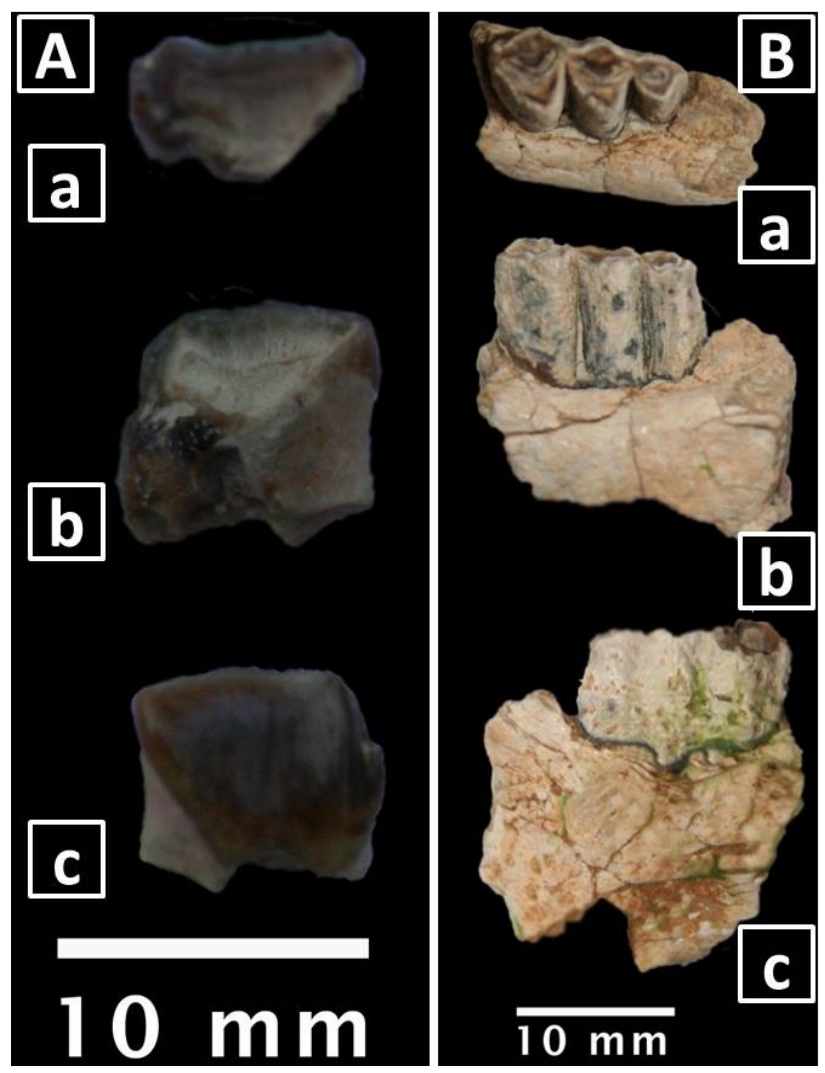

Fig. 4. A, Eotragus noyei. PUPC 16/355, upper left second premolar $\left(\mathrm{P}^{2}\right)$. a, occlusal view; b, lingual view; $\mathrm{c}$, buccal view; B, Eotragus noyei. PUPC 16/356, lower left third molar $\left(\mathrm{m}^{3}\right)$. a, occlusal view; $b$, lingual view; $c$, buccal view.

\section{Comparison}

The studied specimens were collected from Dhok Pathan Formation is correlated with known specimens of genus Eotragus from various localities both of Pakistan as well as other regions of the globe. The morphometric measurements of the studied specimen are close to the 
Eotragus sp. reported by Khan et al. (2009) and E. noyei, and large in E. sansaniensis and E. lampangensis. The size variation is observed among different species of the genus Eotragus based upon the dental size differences reported by Gentry (1999) and Solounias et al. (1995).

The studied specimens as well as comparable species have selenodont morphology and have brachydont teeth. The studied specimen resembles with the other species of the genus Eotragus in having finely rugose enamel. Fossettes are narrow in all the species of genus Eotragus. The buccal walls of the upper molar are more inclined in the studied specimens like E. noyei and Eotragus sp. while in the E. sansaniensis and E. lampangensis are less inclined. Parastyle and mesostyle are of medium size in the studied specimen as well as in the E. noyei and Eotragus sp. whereas well developed in E. lampangensis. In the studied specimen the paracone ribs are stronger than the metacone ribs like E. noyei and Eotragus sp. A trace of lingual cingulum is observed in the studied specimens like E. noyei but it is absent in E. lampangensis and Eotragus sp. of Khan et al. (2009) and large in E. sansaniensis. The $\mathrm{M}^{3}$ metaconule is smaller than the protocone in the studied specimen as well as in the E. noyei, whereas it is relatively larger in other Eotragus species. The $\mathrm{P}^{2}$ protocone is well developed in the studied specimen and situated posteriorly like $E$. noyei. The $\mathrm{P}^{2}$ of the studied specimen has an anterior lingual constriction like in E. noyei, but unlike in other species of Eotragus. In the studied specimen, the lower molars have basal pillar which is clearly visible.

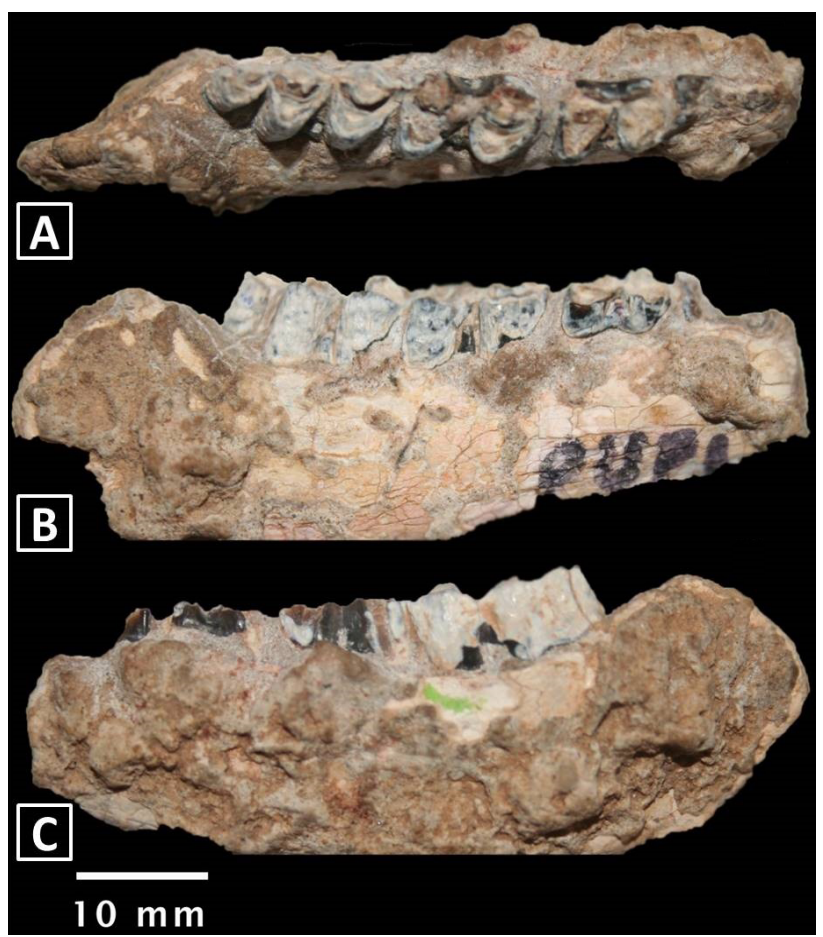

Fig. 5. Eotragus noyei. PUPC 16/357, right mandibular fragment having $\mathrm{P}_{4} \mathrm{M}_{3}$. A, occlusal view; $\mathrm{B}$, lingual view; $\mathrm{C}$, buccal view.

Table II.- Measurements of cheek teeth of studied material of E. noyei taken in mm.

\begin{tabular}{|c|c|c|c|c|c|c|}
\hline Position & & Studied specimen & E. lampangensis & E. noyei & E. sansaniensis & Eotragus sp. \\
\hline \multirow[t]{2}{*}{$\mathrm{p}^{4}$} & $\mathrm{~L}$ & 8.0 & 11.24 & & *11.9 & \\
\hline & $\mathrm{W}$ & 5.0 & & & & \\
\hline \multirow[t]{2}{*}{$\mathrm{m}^{1}$} & $\mathrm{~L}$ & 8.0 & 11.4 & 9.4 & $* 12.2$ & 8.0 \\
\hline & $\mathrm{W}$ & 6.5 & & 6.2 & & 5.0 \\
\hline \multirow[t]{2}{*}{$\mathrm{m}^{2}$} & $\mathrm{~L}$ & 10.0 & & 11.6 & $* * 10.7$ & 8.0 \\
\hline & $\mathrm{W}$ & 6.0 & & 7.9 & 7.8 & 5.6 \\
\hline \multirow[t]{2}{*}{$\mathrm{m}^{3}$} & $\mathrm{~L}$ & 13.0 & 17.25 & 14.2 & $* * 15.0$ & 11.7 \\
\hline & $\mathrm{W}$ & 6.5 & & 7.0 & 7.6 & 4.3 \\
\hline \multirow[t]{2}{*}{$\mathrm{P}^{2}$} & $\mathrm{~L}$ & 7.5 & 9.65 & 8.2 & & \\
\hline & $\mathrm{W}$ & 5.0 & & 5.9 & & \\
\hline \multirow[t]{2}{*}{$\mathrm{P}^{3}$} & $\mathrm{~L}$ & 8.0 & 9.7 & & & \\
\hline & $\mathrm{W}$ & 7.0 & & & & \\
\hline \multirow[t]{2}{*}{$\mathrm{P}^{4}$} & $\mathrm{~L}$ & 6.0 & & 6.5 & & \\
\hline & $\mathrm{W}$ & 6.5 & & 10.3 & & \\
\hline \multirow[t]{2}{*}{$\mathrm{M}^{1}$} & $\mathrm{~L}$ & 7.5 & & 10.1 & & 8.0 \\
\hline & $\mathrm{W}$ & 8.0 & & 10.5 & & 7.0 \\
\hline \multirow[t]{2}{*}{$\mathrm{M}^{2}$} & $\mathrm{~L}$ & 8.0 & & 10.7 & & 9.0 \\
\hline & $\mathrm{W}$ & 9.0 & & & & 7.3 \\
\hline \multirow[t]{2}{*}{$\mathrm{M}^{3}$} & $\mathrm{~L}$ & 9.0 & 13.3 & 10.4 & $* 12.5$ & 9.0 \\
\hline & $\mathrm{W}$ & 8.0 & & 10.7 & & 7.3 \\
\hline
\end{tabular}


Thus, the described specimens have selenodont morphology, brachydont teeth, finely rugose enamel, small lingual cingula, third upper molar $\left(\mathrm{M}^{3}\right)$ metaconule is smaller than the protocone, second upper premolar $\left(\mathrm{P}^{2}\right)$ protocone is located posteriorly and anterior lingual constriction, which indicate, that the specimen belong to the E. noyei.

\section{DISCUSSION}

The physical appearance of the studied specimen shows that they belong to the same individual. The described specimens are square and tetratuberculate, which is the characteristic of herbivorous mammals. The molars have selenodonty pattern which confirms its inclusion to the suborder Ruminantia of the order Artiodactyla. Several morphological features such as less bulky stylids and ribs; crests of the cusps jointed up in early wear; obliquely situated hypoconulid; confluence of the protocristid, metacristid, postmetacristid, and weak cingula. are the characters. which represent Eotragus genus (Rössner, 2006; Gentry, 1999). Described morphological features of the specimen, for instance, finely rugose enamel, obliquely placed teeth without lined up buccal walls, small lingual cingula, P2 protocone is well formed which is situated posteriorly and possess an anteriorly placed lingual constriction, confluence of the protocristid, postmetacristid, and metacristid, brachydont teeth, medium sized parastyle and mesostyle allowed to include them in E. noyei (Alfarez et al., 1980; van der Made, 2012).

Solounias et al. (1995) had been erected E. noyei from the Lower Siwaliks owing to their horn core, five postcranial specimens and a cranial specimen having a probable age between 18.0 and $18.3 \mathrm{Ma}$ (Barry and Flynn, 1989). It is regarded as the smallest and oldest species of Eotragus genus. Morphologically and morphometrically, comparisons were made with specimen GSP-Y 41459 studied by Solounias et al. (1995), PUPC 69/272, PCGCUF 08/01 studied by Khan (2008) from the Lower Siwaliks and with specimen PUPC 04/24, PUPC 05/11, PUPC 04/23 recovered by Khan et al. (2009) from the middle Siwaliks. The studied specimens have great resemblance to the specimen described by Solounias et al. (1995). Size of the studied specimen is slightly small as compared to the specimen which was recovered by Solounias et al. (1995) from the lower Siwaliks. The animal discovered in the Lower Siwaliks has bigger size in comparison to the animal present in the Middle Siwaliks (Khan, 2008; Solounias et al., 1995). The Eotragus is known to be belonging to Europe's Late Early Miocene (15 Ma, MN6; Gentry, 1999; Mein, 1989), Pakistan (18-5 Ma; Khan, 2008; Khan et al., 2009; Solounias et al., 1995) and from China's Middle Miocene (16 Ma; Ye, 1989). The specimens recovered from Pakistan, belonging to the Eotragus sp. have reported to be from the Middle to Early Miocene Gaj Formation of Sindh (Thomas, 1984), the Early Miocene deposits from Dhok Bin Mir Khatoon (Khan, 2008) and the Late Miocene from the Dhok Bun Ameer Khatoon Formation of district Chakwal, mentioned a complete chronological range of 18.3-5.0 Ma from the Lower to Middle Siwaliks. Khan et al. (2009) reported the occurrence of Eotragus $s p$. firstly from the Middle Siwaliks. The new finding of Eotragus extends the stratigraphic area of the genus from Lower Siwaliks to Middle Siwaliks (18.3 Ma to 5.0 Ma).

\section{CONCLUSION}

New fossil remains that belongs to E. noyei are recovered from the Dhok Pathan Formation, Middle Siwaliks of the Potwar Plateau of Pakistan. The discovery of E. noyei from Dhok Pathan Formation considerably extends the geographic range of this taxon from the Lower Siwaliks to the Middle Siwaliks. The collected specimens consist of upper and lower premolars and molars. These specimens strengthen the existence of species in Dhok Pathan Formation of Middle Siwaliks at about 8.5-9 Ma. The diversity of Dhok Pathan fauna is very helpful in understanding and reconstructing the palaeoenviroment and palaeohabitat of animals that have ever been existed in locality of Dhok Pathan Formation. It is considered that $E$. noyei is the oldest and smallest species of the genus Eotragus as well as the oldest bovid found until then (Solounias et al., 1995). The selenodonty of the ruminants may be interpreted for fibrous foods which may have been the swamp vegetation due to the depositional environment. The combined occurrence of such taxa in the Dhok Pathan locality proposes open but no grassy habitats, which includes some constituents of fairly abrasive vegetation like long grasses (Janis and Scott, 1988; Cerling et al., 1997).

\section{Statement of conflict of interest}

The authors declare no conflict of interest.

\section{REFERENCES}

Alfarez, F., Villalta, J.F. and de Moya, S., 1980. Primera cita en España del antelope mas antiguo de Europa, Eotragus artenensis, Ginsburg y Heintz, 1968 (Mammalia, Bovidae), Procedente del Orleaniense de Corcoles (Guadalajara). Rev. COL$P A$, 36, Editorial de la Universidad Complutense de Madrid, pp. 1-131. 
Badgley, C., Barry, J.C., Morgan, M.E., Velson, S.V., Behrensmeyer, A.K., Cerling, T.E. and Pilbeam, D., 2008. Ecological changes in Miocene mammalian record show impact of prolonged climatic forcing. Proc. natl. Acad. Sci., 105: 12145-12149. https:// doi.org/10.1073/pnas.0805592105

Barry, J.C., Behrensmeyer, A.K., Badgley, C.E., Flynn, L.J., Peltonen, H.A.N.N.E.L.E., Cheema, I.U., Pilbeam, D.A.V.I.D., Lindsay, E.H., Raza, S.M., Rajpar, A.R. and Morgan, M.E., 2013. The Neogene Siwaliks of the Potwar Plateau, Pakistan. In: Fossil mammals of Asia: Neogene biostratigraphy and chronology. Columbia University Press, New York, pp. 373-399. https://doi.org/10.7312/ columbia/9780231150125.003.0015

Barry, J.C., Johnson, N.M., Raza, S.M. and Jacobs, L.L., 1985. Neogene mammalian faunal change in southern Asia: Correlations with climatic, tectonic, and eustatic events. Geology, 13: 637-640. https:// doi.org/10.1130/0091-7613(1985)13<637:NMFCI $\mathrm{S}>2.0 . \mathrm{CO} ; 2$

Barry, J.C., Morgan, M., Flynn, L., Pilbeam, D., Behrensmeyer, A.K., Raza, S., Khan, I., Badgely, C., Hicks, J. and Kelley, J., 2002. Faunal and environmental change in the Late Miocene Siwaliks of Northern Pakistan. Paleobiology, 28: $\quad 1-72$. https://doi.org/10.1666/00948373(2002)28[1:FAECIT]2.0.CO;2

Barry, J.C. and Flynn, L.J., 1989. Key biostratigraphic events in the Siwalik sequence. In: European Neogene mammal chronology (eds. E.H. Lindsay, V. Fahlbusch and P. Mein). NATO ASI Series A 180, Plenum Press, New York, pp. 557-571. https:// doi.org/10.1007/978-1-4899-2513-8_33

Barry, J.C., Lindsay, E.H. and Jacobs, L.L., 1982. A biostratigraphic zonation of the middle and upper Siwaliks of the Potwar Plateau of northern Pakistan. Palaeogeogr. Palaeoclimatol. Palaeoecol., 37: 95130. https://doi.org/10.1016/0031-0182(82)900591

Behrensmeyer, A.K. and Tauxe, L., 1982. Isochronous fluvial systems in Miocene deposits of Northern Pakistan. Sedimentology, 29: 331-352. https://doi. org/10.1111/j.1365-3091.1982.tb01799.x

Bibi, F., 2007. Origin, paleoecology, and paleobiogeography of early Bovini. Palaeogeogr. Palaeoclimatol. Palaeoecol., 248: 60-72. https:// doi.org/10.1016/j.palaeo.2006.11.009

Bibi, F., 2009. Evolution, systematics, and paleoecology of Bovinae (Mammalia: Artiodactyla) from the Late Miocene to the recent. Ph. D. thesis, Yale University, New Haven.
Cerling, T.E., Harris, J.M., MacFadden, B.J., Leakey, M.G., Quade, J., Eisenmann, V. and Ehleringer, J.R., 1997. Global vegetation change through the Miocene/Pliocene boundary. Nature, 389: 153-158. https://doi.org/10.1038/38229

Flynn, L.J., Pilbeam, D., Barry, J.C., Morgan, M.E. and Raza, S.M., 2016. Siwalik synopsis: A long stratigraphic sequence for the Later Cenozoic of South Asia Synopsis Siwalik: longue succession stratigraphique du Cénozoïque moyen et. tardif de l'Asie du Sud. C. R. Palevol., 15: 877-887. https:// doi.org/10.1016/j.crpv.2015.09.015

Gentry, A.W., 1994. The Miocene differentiation of Old World Pecora (Mammalia). Hist. Biol., 7: 115-158. https://doi.org/10.1080/10292389409380449

Gentry, A.W., 1999. Fossil Pecorans from the Baynunah Formation, Emirate of Abu Dhabi, United Arab Emirates. In: Fossil vertebrates of Arabia (eds. P.J. Whybrow and A.P. Hill). Yale University Press, New Haven, pp. 290-316.

Haile-Selassie, Y., Suwa, G. and White, T.D., 2004. Late Miocene teeth from Middle Awash, Ethiopia, and early Hominid dental evolution. Science, 303: 15031505. https://doi.org/10.1126/science.1092978

Janis, C.M. and Scott, K.M., 1988. The phylogeny of the Ruminantia (Artiodactyla, Mammalia). In: The phylogeny and classification of Tetrapods, Volume 2: Mammals (ed. M.J. Benton). Systematics Association Special Volume, Academic Press Systematics Association, London-New York, pp. 273-282.

Khan, M.A., 2008. Fossil bovids from the Late Miocene of Padhri, Jhelum, Pakistan. Pakistan J. Zool., 40: 25-29.

Khan, M.A., Iliopoulos, G. and Akhtar, M., 2009. Boselaphines (Artiodactyla, Ruminantia, Bovidae) from the Middle Siwaliks of Hasnot, Pakistan. Geobios, 42: 739-753. https://doi.org/10.1016/j. geobios.2009.04.003

Mein, P., 1989. Updating of the MN zones. In: European Neogene mammal chronology (eds. E.H. Lindsay and V. Fahlbusch). NATO ASI Series A 180, Plenum Press, New York, pp. 73-90. https://doi. org/10.1007/978-1-4899-2513-8_6

Morgan, M.E., Behrensmeyer, A.K., Badgley, C., Barry, J.C., Nelson, S. and Pilbeam, D., 2009. Lateral trends in carbon isotope ratios reveal a Miocene vegetation gradient in the Siwaliks of Pakistan. Geology, 37: 103-106. https://doi.org/10.1130/ G25359A.1

Rössner, G.E., 2006. A community of Middle Miocene Ruminantia (Mammalia, Artiodactyla) from the 
German Molasse Basin. Palaeontogr. Abteil. A, 277: 103-112.

Solounias, N., Barry, J.C., Bernor, R.L., Lindsay, E.H. and Raza, S.M., 1995. The oldest Bovid from the Siwaliks, Pakistan. J. Verteb. Paleontol., 15: 806814. https://doi.org/10.1080/02724634.1995.1001 1263

Solounias, N. and Moelleken, S.M.C., 1992. Dietary adaptations of two goat ancestors and evolutionary considerations. Géobios, 25: 797-809. https://doi. org/10.1016/S0016-6995(92)80061-H

Suraprasit, K., Chaimanee, Y., Bocherens, H., Chavasseau, O. and Jaeger, J., 2014. Systematics and phylogeny of middle Miocene Cervidae (Mammalia) from Mae Moh Basin (Thailand) and a paleoenvironmental estimate using enamel isotopy of sympatric herbivore specie. J. Vertebr. Paleontol., 34: 179-194. https://doi.org/10.1080/02724634.20
13.789038

Thomas, H., 1984. Les bovidés ante-hipparions des Siwaliks inférieurs (plateau du Potwar), Pakistan. Mém. Soc. Géol. France, 145: 1-68.

van der Made, J., 2012. Eotragus clavatus (Artiodactyla, Bovidae, Boselaphini) de Sansan. In: Mammifères de Sansan (eds. S. Peigne and S. Sen). Mem. Mus. natl. Hist. Nat., 203: 145-199. ISBN: 978-2-85653681-0.

Waseem, M.T., Sarwar, M.A., Ahmad, R.M. and Khan, A.M., 2016. Newly discovered fossil remains of Selenoportax vexillarius from Hasnot, locality of Siwaliks of Pakistan. Punjab Univ. J. Zool., 31: 5358.

Ye, J., 1989. Middle Miocene artiodactyls from the northern Junggar Basin. Verteb. Palasiat., 27: $37-$ 52. 